\title{
Tight Sandstone Reservoir Formation Mechanism of Upper Paleozoic Buried Hills in the Huanghua Depression, Bohai Bay Basin, Eastern China
}

\author{
Lihong Zhou ${ }^{1}$, Yong Li ${ }^{1,2}, * \mathbb{D}$, Fengming Jin ${ }^{1}$, Lixin Fu ${ }^{1}$, Xiugang Pu ${ }^{1}$, Lou Da ${ }^{1}$, Hongjun Li ${ }^{1}$, Haitao Liu ${ }^{3}$ \\ and Weikai $\mathrm{Xu}^{2}$
}

check for

updates

Citation: Zhou, L.; Li, Y.; Jin, F.; Fu, L.; Pu, X.; Da, L.; Li, H.; Liu, H.; Xu, W. Tight Sandstone Reservoir Formation Mechanism of Upper Paleozoic Buried Hills in the Huanghua Depression, Bohai Bay Basin, Eastern China. Minerals 2021, 11, 1368. https://doi.org/10.3390/min11121368

Academic Editor: Leszek Marynowski

Received: 18 November 2021 Accepted: 30 November 2021 Published: 3 December 2021

Publisher's Note: MDPI stays neutral with regard to jurisdictional claims in published maps and institutional affiliations.

Copyright: (c) 2021 by the authors. Licensee MDPI, Basel, Switzerland. This article is an open access article distributed under the terms and conditions of the Creative Commons Attribution (CC BY) license (https:// creativecommons.org/licenses/by/ $4.0 /)$.
1 Dagang Oilfield Company, PetroChina, Tianjin 300280, China; zhoulh@petrochina.com.cn (L.Z.); yjy_jfm@petrochina.com.cn (F.J.); fulxin@petrochina.com.cn (L.F.); puxgang@petrochina.com.cn (X.P.); louda@petrochina.com.cn (L.D.); dg_lihjun1@petrochina.com.cn (H.L.)

2 College of Geosciences and Surveying Engineering, China University of Mining and Technology, Beijing 100083, China; 18810000743@163.com

3 Research Institute of Petroleum Exploration and Development, Beijing 100083, China; liu_haitao@petrochina.com.cn

* Correspondence: liyong@cumtb.edu.cn; Tel.: +86-159-0101-9002

\begin{abstract}
Carboniferous-Permian petroleum resources in the Huanghua Depression of the Bohai Bay Basin, a super petroleum basin, are important exploration successor targets. The reservoir sedimentary environment of coal measures in the Upper Paleozoic buried hills is variable, and the structural evolution process is complicated, which restricts the optimization of targeting sections. Using the analysis and testing results of logging, thin section, porosity, mercury injection, hydrochemistry, and basin simulation, this study revealed the formation mechanism differences of tight sandstones in the Upper Paleozoic period in different buried hills. The results show that the sandstones are mainly feldspathic sandstone, lithic arkose, feldspathic lithic sandstone, and feldspathic lithic quartz sandstone. The quartz content varies between $25 \%$ and $70 \%$, averaging $41 \%$. Feldspar and debris are generally high, averaging $31 \%$ and $28 \%$, respectively. Secondary dissolution pores are the main reservoir spaces, with $45 \%$ of the tested samples showing porosity of $5-10 \%$, and $15 \%$ being lower than $5 \%$. The pore radium is generally lower than $100 \mathrm{~nm}$, and the sandstones are determined as small pore with fine throat and medium pore with fine throat sandstones by mercury saturation results. Frequent changing sedimentary environments and complex diagenetic transformation processes both contribute to the reservoir property differences. The former determines the original pore space, and the latter determines whether they can be used as effective reservoirs by controlling the diagenetic sequences. Combining tectonic movement background and different fluid history, the different formation mechanisms of high-porosity reservoirs are recognized, which are atmospheric leaching dominated (Koucun buried hills), atmospheric water and organic acid co-controlled (Wangguantun and Wumaying buried hills), and organic acid dominated (Nandagang buried hills) influences. The results can be beneficial for tight gas exploration and development in coal measures inside clastic buried hills in the Bohai Bay Basin.
\end{abstract}

Keywords: tight gas; coal measures; diagenetic transformation; tectonic superposition; Bohai Bay Basin

\section{Introduction}

China is rich in coal-derived tight gas resources, accounting for approximately $60 \%$ of the country's natural gas resources, and is a key area for unconventional natural gas exploration and development [1-3]. China is expected to have a gas production of $2500 \times 10^{8} \mathrm{~m}^{3}$ in 2025, reaching or being close to the present annual production of the United States, Russia, and Iran [4]. The Bohai Bay Basin is an offshore extension in a series of prolific oil-producing basins in NE China, which is also a super basin with huge oil and gas 
production $[5,6]$. However, the Upper Paleozoic tight gas still cannot be commercially produced, even though breakthroughs have been observed in different buried hills, such as Wangguantun, Wumaying, and Chenghai buried hills [7,8].

The Upper Paleozoic period in the Bohai Bay Basin experienced long-term tectonic evolution both in the Mesozoic and Cenozoic periods, with multiple subsidences and uplifts $[9,10]$. The diagenetic sequences of tight sandstones in the Carton basins, such as the Ordos and Sichuan basins, have been studied extensively [11,12]. The diagenesis of sandstones in different regions during the superimposed evolution of the basin varies significantly, and the reservoir heterogeneity is strong $[13,14]$. Presently, there are limited studies on the mechanisms and distribution of high-quality tight gas reservoirs in different buried hills, as different buried hills generally have different tectonic evolution histories.

The physical properties of tight sandstone and its controlling factors in the Upper Paleozoic period in the Bohai Bay Basin was investigated, and the purpose was 3-fold: (1) to analyze sandstone composition and pore types differences considering depositional environment; (2) to discuss different tectonic evolution histories based on different tectonic movement; and (3) to reveal high-quality tight sandstone reservoir formation mechanisms. Based on the above analysis, differential reservoir formation models for Upper Paleozoic tight sandstones were established considering future tight gas exploration.

\section{Geological Setting}

The Huanghua Depression is a secondary structural unit in the Bohai Bay Basin, which borders the Jiyang Depression and Bozhong Depression in the east and the Jizhong Depression in the west $[15,16]$. It is structurally a northeast-southwest depression, located in the Yanshan EW trending structure, the Taihangshan NE-trending structure, and the southern arc of the Bohai Bay Basin [17]. The area is rich in petroleum resources, with multiple sets of source rocks, such as the second to third members of the Shahejie Formation and the Carboniferous-Permian and multiple sets of reservoir-caprock assemblages $[18,19]$. Among them, the Carboniferous-Permian Upper Paleozoic clastic buried hill has attracted much attention because of its variable sedimentary process and complex diagenetic transformation.

The Upper Paleozoic in the Huanghua Depression is an epicontinental to continental sedimentary system with a stable craton background, which can be divided into multiple types of buried hills based on the tectonic background of the Mesozoic and Cenozoic periods (Figure 1). The strata can be divided into Carboniferous and Permian, which are a set of coal-bearing structural deposits of marine-terrestrial facies (Figure 1b). From bottom to top, the Benxi Formation, Taiyuan Formation, Shanxi Formation, and Xiashihezi Formation develop in sequence. In the Late Indosinian period, uplifts and folds were formed by north-south compression, and the superimposition of derived structures resulted in obvious stratigraphic differences. The Carboniferous-Permian in the southern area was relatively intact, and the northern area suffered differential denudation, with some areas being completely denuded (Figure 1c). 


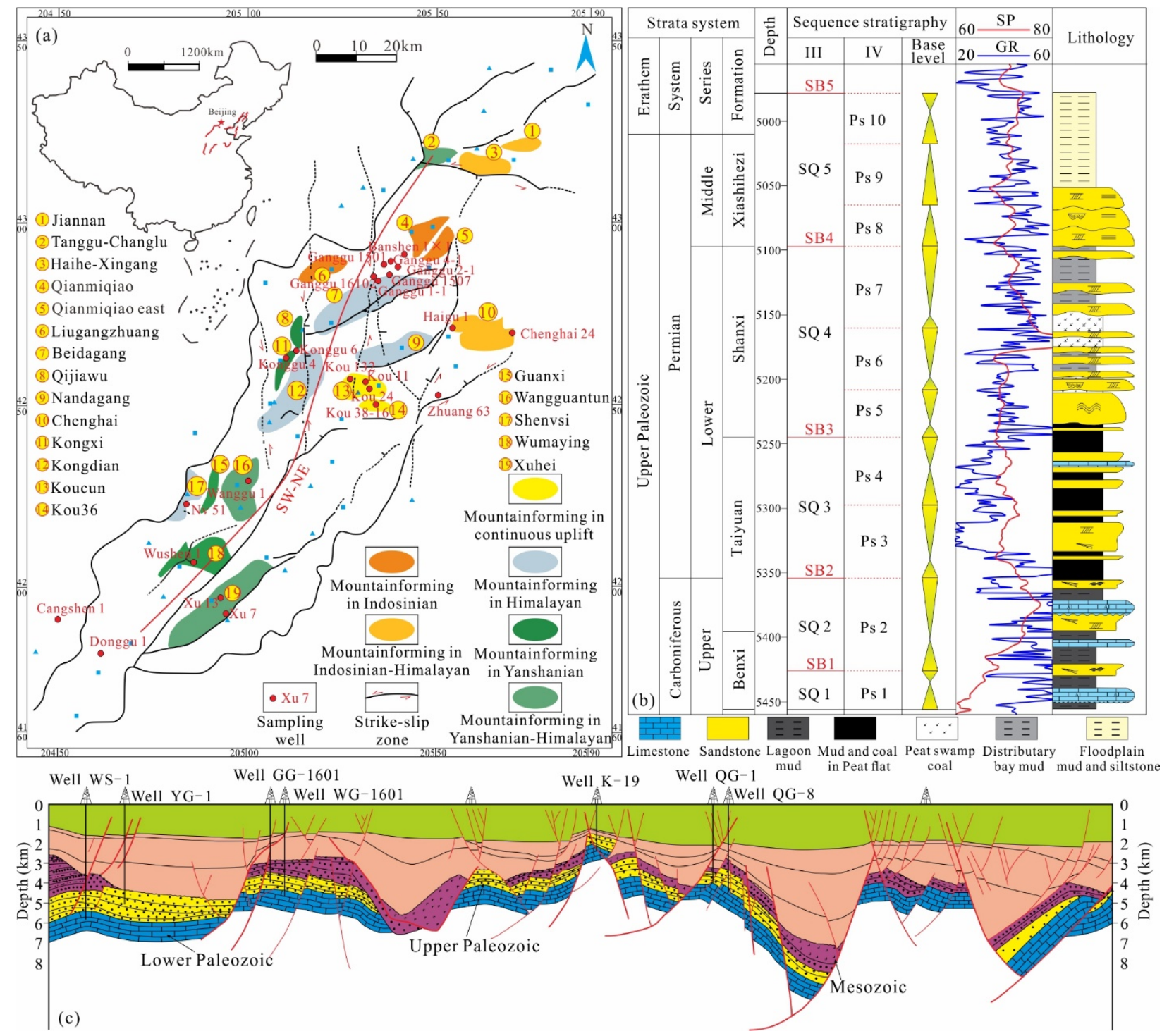

Figure 1. Comprehensive geological map of the Huanghua Depression in the Bohai Bay Basin. (a), Regional and buried hills distribution in the Huanghua Depression; (b), Comprehensive strata column in the Huanghua Depression; (c), SW-NE stratigraphic section of the main buried hills in the Huanghua Depression. SB: Sequence boundary, SQ: Sequence, GR: Natural Gamma, Ps: Parasequence, WS: Wushen, QG: Qigu, GG: Ganggu.

\section{Materials and Methods}

More than 100 samples from 25 core wells drilled into the Carboniferous-Permian system in the study area were subjected to conventional physical property analysis, $\mathrm{X}$-ray diffraction whole-rock composition analysis, mercury intrusion, scanning electron microscope observation, cast thin section and fluorescent thin section observation, and groundwater isotope tests. The locations of all sampling wells have been marked in Figure 1.

Microscopic observation, including pore types and mineral compositions was conducted using a DMLP Polarizing Microscope produced by the Leica company (Wezlar, Germany), model $217400[20,21]$. Mineral point counting was used to determine the mineralogical characteristics and porosity of thin sections [22,23]. The maximum error range varies with the percentage of composition, from $-3.6 \%$ at $50 \%$ content to $-2.1 \%$ at $10 \%$ content. Each sample was quantified at approximately 200 points. A separated aqueous solution was used for the hydrogen and oxygen isotope analyses of groundwater. The zinc reduction method was used to prepare the hydrogen. The hydrogen isotopes of the water samples were analyzed. MAT 253 stable isotope mass spectrometer produced 
by Thermo Fisher Scientific (Bremen, Germany) GmbH was used in the experiment. The $\mathrm{CO}_{2}-\mathrm{H}_{2} \mathrm{O}$ balance method was used to analyze the oxygen isotope of water, and the result was indicated as the relative $\delta \mathrm{V}$-SMOW value [24].

The conventional physical property test uses a vacuum pressure saturation device, DZSY-001 (Haian Petroleum Instrument Company, Nantong, China), and rock permeability tester, DZSY-002 (Haian Petroleum Instrument Company, Nantong, China), at $25^{\circ} \mathrm{C}$ in a $35-50 \%$ humid environment [21]. A D/max-2200 X-ray diffractometer 2035C4 produced by Olympus (Tokyo, Japan) was used to analyze the total rock content and the relative content of clay minerals, and the analysis data were processed by Clayquan (2018 version, Research Institute of Petroleum Exploration and Development, Beijing, China) [20,25]. JSM$5500 \mathrm{LV}$ produced by the JEOL (Akishima, Japan) company in Japan was used to perform scanning electron microscopy (SEM) [26]. The detection environment, i.e., temperature and humidity, was $25{ }^{\circ} \mathrm{C}$ and $40 \%$, respectively, and the samples were all plated with gold during sample preparation.

Mercury porosimetry was conducted using an Autopore IV 9500 produced by American Micromeritics high-pressure mercury injection experiment produced by the Micromeritics Instrument Corporation of the United States (Norcross, Georgia) [27]. Two key parameters in the mercury injection curve, the displacement pressure $P_{\mathrm{d}}$ and the mercury saturation median pressure $P_{50}$, were selected to characterize the pore structure. $P_{\mathrm{d}}$ refers to the capillary pressure of the largest connected pore in the pore structure, reflecting the maximum pore-throat connection radius $R_{\max }$. $P_{50}$ refers to the capillary pressure corresponding to the mercury penetration curve when the mercury saturation is $50 \%$ and represents the distribution characteristics of the pore-throat size.

\section{Results}

\subsection{Sandstone Composition}

The tight sandstones are mainly feldspar sandstone, lithic feldspar sandstone, feldspar lithic sandstone, and feldspar lithic quartz sandstone and generally have low composition and structural maturity (Figure 2). Among them, the quartz content is mainly concentrated between $25 \%$ and $70 \%$, with an average of $40.77 \%$. Feldspar is mainly concentrated between $10 \%$ and $55 \%$, with an average of $30.77 \%$, mainly K-feldspar. The content of debris is mainly concentrated between $5 \%$ and $60 \%$, with an average of $28.44 \%$. The particle size distribution range of sandstone particles is mainly $0.1-0.25 \mathrm{~mm}$, the textural maturity is medium, and the roundness of the particles is mainly sub-angular to subcircular.

Different dominant sedimentary microfacies sandstone types generally have similar characteristics, are controlled by similar hydrodynamic conditions, and have certain similarities in particle size and rock composition [28]. Meandering channels, braided channel bars, delta distributary channels, barrier islands, and barrier sand bars are all developed in areas with strong hydrodynamic conditions in a single depositional unit. The types of sandstone are feldspar sandstone with moderate quartz content, high feldspar or cuttings, lithic feldspar sandstone, feldspar lithic sandstone, and lithic sandstone. Fluvial channels, channel bars, and distributary channels are mainly supplied by terrigenous clastics, with relatively high quartz content, and feldspar lithic quartz sandstones are often developed. The sandstone grain size varied in the study area as follows: channel bar > point bar > distribution channel $>$ barrier sand dam. The corresponding hydrodynamic conditions gradually weaken, and the sedimentary layer is produced because of the transition from large cross bedding to small cross bedding. 


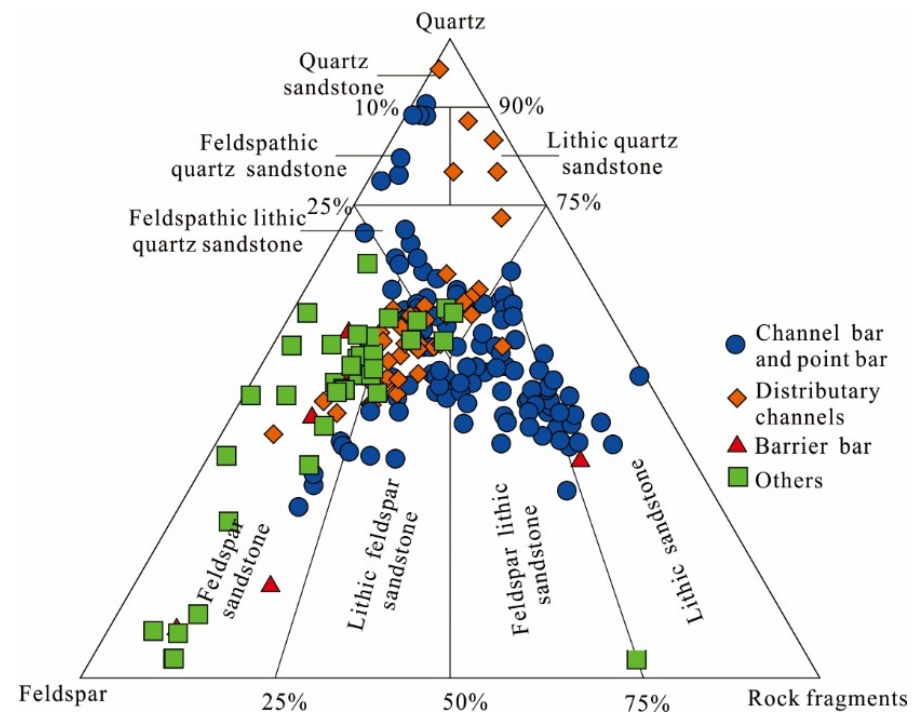

Figure 2. Ternary diagrams of sandstone pore types from different microfacies.

\subsection{Porosity and Permeability}

The coal-measure tight sandstones were generally of low porosity and permeability, of which $15 \%$ were samples with a porosity of less than $5 \%$; samples with a porosity of $5-10 \%$ accounted for $45 \%$, and samples with a porosity greater than $10 \%$ accounted for $30 \%$. The permeability data had a poor correlation with the porosity. The samples from different formation in the Permian and Carboniferous systems all show characteristics of decreasing with depth (Figure 3b). Among them, in the Xiashihezi Formation, the physical properties of the group were the best, followed by the sandstones of the Taiyuan Formation, and the sandstones of the Shanxi Formation had the worst physical properties. The porosity and permeability of sandstone did not always decrease with an increase in burial depth, and sandstone with higher porosity existed in a certain interval. Among them, high-porosity and high-permeability sandstone was mainly developed in the Koucun area, which is obviously affected by diagenesis.

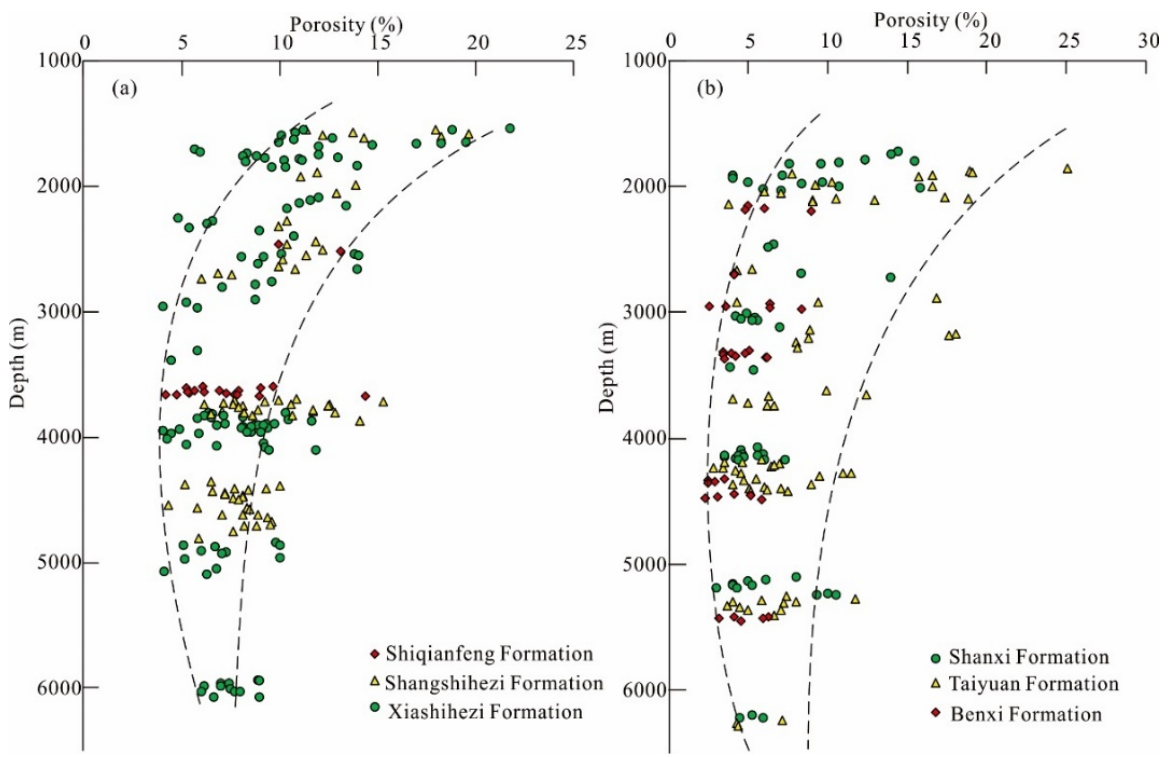

Figure 3. The sandstone porosity varies with burial depth in the study area. (a), Samples from Xiashihezi, Shangshihezi, and Shiqianfeng formations; (b), samples from Shanxi, Taiyuan, and Benxi formations. 


\subsection{Pore Structure \\ 4.3.1. Pore Types}

According to the cast thin sections and SEM images, the pores were dominated by secondary dissolved pores, followed by a few micro-fractures (Figure 4a-i), and the primary pores were rare (Table 1). The secondary dissolution pores can be divided into intergranular dissolution pores and intragranular dissolution pores according to the dissolution position, and intragranular dissolution pores were the main ones. The intragranular dissolution pores were mainly formed by intragranular dissolution of feldspar and cuttings particles, especially intragranular dissolution pores formed by the dissolution of feldspar, and some particles were partly or completely dissolved (Figure $4 \mathrm{~d}-\mathrm{f}$ ). The reservoirs of the Xiashihezi Formation in the Beidagang area had a strong dissolution effect, with a secondary dissolution face rate of up to $6 \%$, and most of the reservoirs had a dissolution face rate of less than $1 \%$.

The fractures in tight sandstone reservoirs of coal measures mainly included fractures formed by the strong compression of particles such as feldspar and quartz, and dissolution fractures in sandstones with high carbonate contents (Figure $4 \mathrm{~g}-\mathrm{i}$ ). Fractures were the most developed in the Carboniferous Taiyuan Formation reservoir, and their opening could reach $30 \mu \mathrm{m}$.
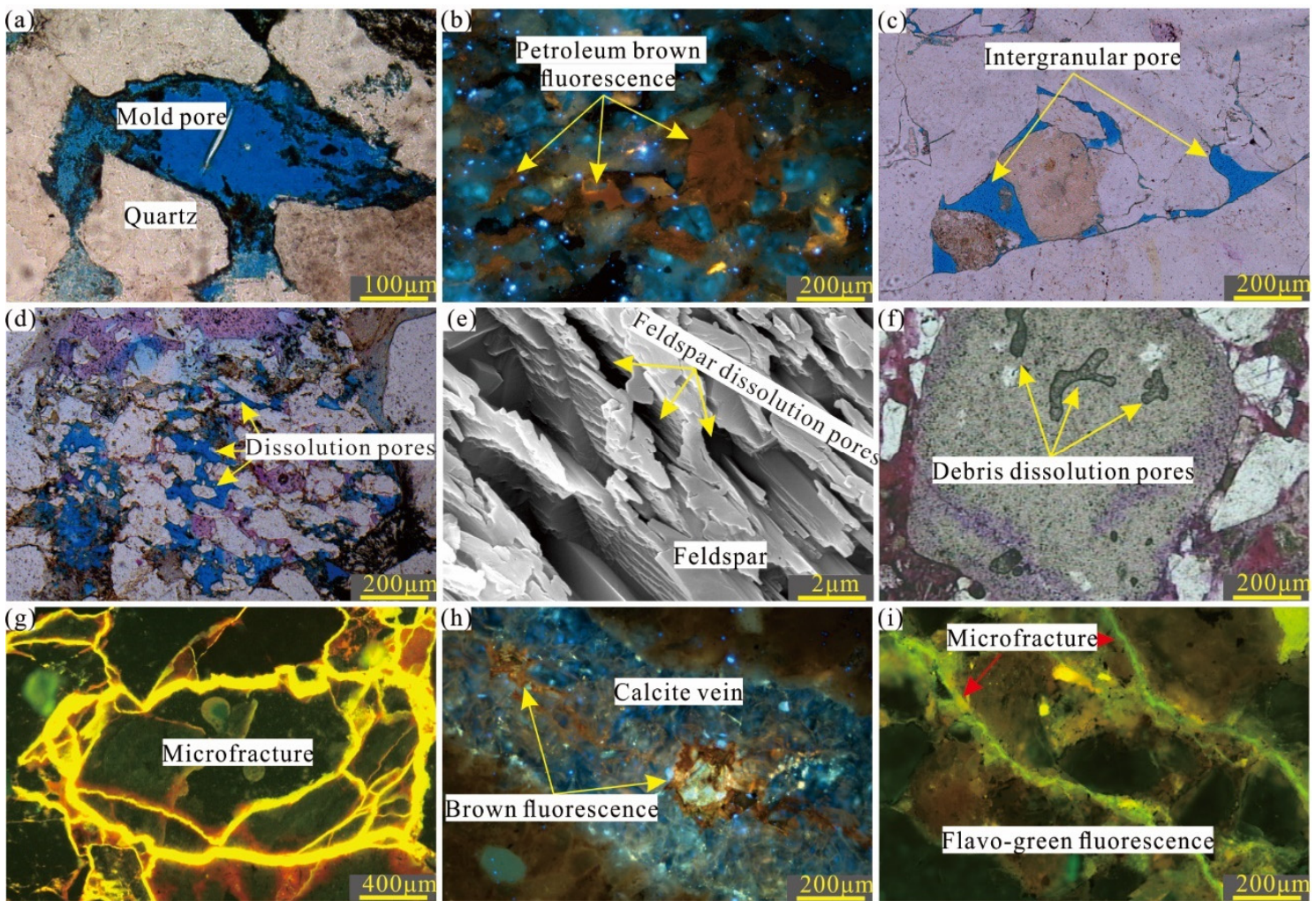

Figure 4. Pore types of the sandstones in the study area. (a), Mold pore, Ganggu 1507 well, $2182.2 \mathrm{~m}$, cast thin section; (b), intergranular pores of sandstone contain oil and gas, showing brown fluorescence, Ganggu 16102 well, $1981.06 \mathrm{~m}$, fluorescent thin section; (c), intergranular pore, Ganggu 16102 well, $2199.03 \mathrm{~m}$, cast thin section; (d), ingrain solution pore, Ganggu 1-1 well, 1782.5 m, cast thin section; (e), feldstone dissolution, Nv 51 well, 2501.98 m, SEM; (f), dissolved pores in cuttings, Ganggu 1501 Well, 2288.34 m, casting thin section; (g), intragranular and intergranular fractures, Well Nv 51, $2500.82 \mathrm{~m}$, fluorescent thin section; (h), sandstone cracks filled with calcite intergranular pores containing oil and gas, showing yellow-brown fluorescence, Ganggu 16102 well, $2187.27 \mathrm{~m}$, fluorescent thin section; (i), intergranular pores and rock micro-fractures filled with light oil and gas, Ganggu 16102 well, 1928.86 m, fluorescent thin section. 
Table 1. Ratio of pores recognized from sandstone thin sections.

\begin{tabular}{cccccc}
\hline Samples & $\begin{array}{c}\text { Residual } \\
\text { Intergranular } \\
\text { Pore (\%) }\end{array}$ & $\begin{array}{c}\text { Intergranular } \\
\text { Dissolution Pore } \\
\mathbf{( \% )}\end{array}$ & $\begin{array}{c}\text { Intragranular } \\
\text { Dissolution Pore } \\
\mathbf{( \% )}\end{array}$ & $\begin{array}{c}\text { Intergranular } \\
\text { Pore (\%) }\end{array}$ & Fractures (\%) \\
\hline Cangshen 1 & 0.00 & 1.60 & 0.30 & 0.79 & 0.15 \\
Donggu 1 & 0.00 & 0.00 & 0.86 & 0.03 & 0.00 \\
Ganggu 16102 & 0.12 & 0.31 & 0.28 & 0.00 & 0.14 \\
Ganggu 2-1 & 0.00 & 0.00 & 1.00 & 0.00 & 0.00 \\
Ganggu 4-1 & 0.00 & 0.00 & 6.00 & 0.00 & 0.00 \\
Konggu 4 & 0.00 & 5.90 & 4.00 & 1.14 & 0.00 \\
Kou 24 & 0.00 & 2.43 & 1.57 & 2.43 & 0.00 \\
Wushen 1 & 0.00 & 1.13 & 0.00 & 0.00 & 0.00 \\
Zhuang 63 & 0.00 & 2.25 & 0.25 & 0.05 & 0.00 \\
\hline
\end{tabular}

\subsubsection{Pore Throat Structure}

To accurately describe the difference in pore structure, $P_{\mathrm{d}}$ and $P_{50}$ were used to divide the pore structure of the study area into six categories (Table 2). The type I pore structure was a small pore and micro throat type, with high drainage pressure, and the maximum mercury saturation was far below $50 \%$; the storage capacity was extremely poor. The type II pore structure was a small pore and fine throat type, which was biased toward fineness. The mercury injection curve was flat, with a high discharge pressure, and the maximum mercury saturation was less than $50 \%$, indicating poor storage capacity and weak percolation. Types III and IV pore structures were of mesoporous and fine throat type, and the displacement pressure was relatively reduced. Although small, the maximum mercury inlet saturation was greater than $50 \%$, indicating that the storage capacity was relatively good. The type $\mathrm{V}$ pore structure consisted of the mesopore and middle throat type, which was biased toward fineness; the mercury injection curve no longer had a plateau, the discharge pressure was further reduced, and the maximum mercury inlet saturation was large. The type VI pore structure consisted of large pores and medium throat type, which was biased toward coarseness; the pressure curve platform slowed down, the pore throat distribution was uniform, the connectivity was good, the maximum mercury saturation was high, and the reservoir had superior performance. The pore structure of tight sandstone in coal measures in the study area was mainly of types II, III, and IV, of which type IV reservoirs were mainly developed in Beidagang buried hills (Figure $5 b$ ). On this basis, the pore throat radius distributions of 10 samples were calculated (Table 3). The results show that a radius less than $10 \mathrm{~nm}$ accounts for about 20.21-66.48\%, the radius between 10 and $100 \mathrm{~nm}$ accounts for about $27.41-65.78 \%$, the content between 100 and $1000 \mathrm{~nm}$ is less, accounting for only $0.03-18.78 \%$, and the content greater than $1000 \mathrm{~nm}$ is rare.

Table 2. Pore type classification from mercury porosimetry. /: means no data.

\begin{tabular}{|c|c|c|c|c|c|c|}
\hline \multirow{2}{*}{ Parameter } & \multicolumn{6}{|c|}{ Pore Structure Types } \\
\hline & Type I & Type II & Type III & Type IV & Type V & Type VI \\
\hline$P_{\mathrm{d}}(\mathrm{MPa})$ & $0.08-15.38$ & $0.09-3.97$ & $0.09-1.76$ & $0.09-0.74$ & $0.05-0.25$ & $0.12-0.13$ \\
\hline$P_{50}(\mathrm{MPa})$ & / & $6.62-29.84$ & $2.70-13.58$ & $1.39-6.37$ & $0.66-2.38$ & $0.09-1.06$ \\
\hline$R_{\max }(\mu \mathrm{m})$ & $0.05-3.45$ & $0.25-8.17$ & $0.42-8.00$ & $1.00-8.24$ & $2.96-15.00$ & $0.09-1.06$ \\
\hline $\begin{array}{c}\text { Average } \\
\text { aperture }(\mu \mathrm{m})\end{array}$ & $0.06-12.90$ & $0.25-23.34$ & $0.48-20.89$ & $0.64-25.56$ & $2.78-13.50$ & 3.33-11.55 \\
\hline Pore structure & $\begin{array}{l}\text { Small pore with } \\
\text { microthroat }\end{array}$ & $\begin{array}{l}\text { Small pore with } \\
\text { fine throat }\end{array}$ & $\begin{array}{l}\text { Medium pore } \\
\text { with fine throat }\end{array}$ & $\begin{array}{l}\text { Medium pore } \\
\text { with fine throat }\end{array}$ & $\begin{array}{c}\text { Medium pore } \\
\text { with medium } \\
\text { throat }\end{array}$ & $\begin{array}{l}\text { Macropore with } \\
\text { medium throat }\end{array}$ \\
\hline
\end{tabular}

Note: $P_{\mathrm{d}}$ is the displacement pressure (MPa), $P_{50}$ is the median pressure of mercury saturation (MPa), and $R_{\max }$ is the maximum pore throat connection radius $(\mu \mathrm{m})$. 

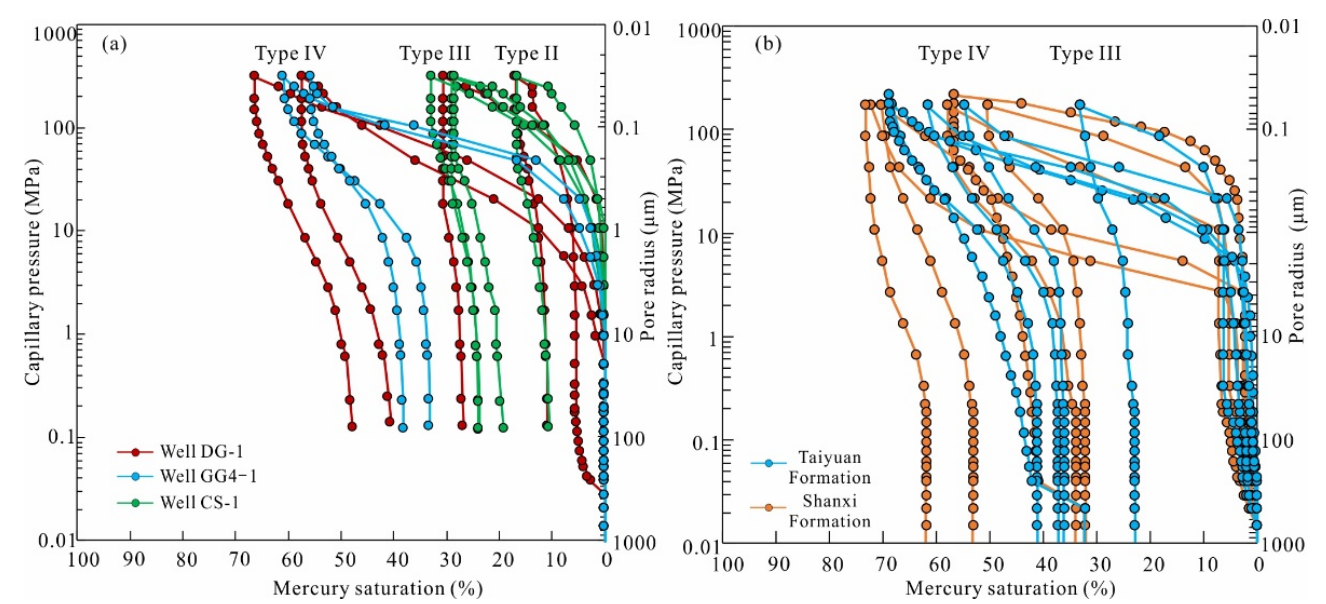

Figure 5. Mercury porosimetry revealed pore types in the study area. (a), Differences between wells; (b), differences between Shanxi and Taiyuan Formations.

Table 3. Pore structure distribution by mercury porosimetry.

\begin{tabular}{|c|c|c|c|c|}
\hline \multirow{2}{*}{ Samples } & \multicolumn{4}{|c|}{ Pore Sizes Proportions (\%) } \\
\hline & $<10 \mathrm{~nm}$ & $10-100 \mathrm{~nm}$ & $100-1000 \mathrm{~nm}$ & $>1000 \mathrm{~nm}$ \\
\hline DG-1-1 & 35.82 & 53.94 & 9.61 & 0.63 \\
\hline DG-1-2 & 20.21 & 58.09 & 18.78 & 2.92 \\
\hline DG-1-3 & 56.79 & 40.95 & 2.26 & 0.00 \\
\hline DG-1-4 & 33.60 & 29.44 & 4.12 & 32.84 \\
\hline GG4-1-1 & 25.69 & 65.78 & 8.53 & 0.00 \\
\hline GG4-1-2 & 40.97 & 54.82 & 4.21 & 0.00 \\
\hline CS-1-1 & 53.98 & 39.64 & 6.38 & 0.00 \\
\hline CS-1-2 & 59.54 & 31.80 & 8.66 & 0.00 \\
\hline CS-1-3 & 53.33 & 46.64 & 0.03 & 0.00 \\
\hline CS-1-4 & 66.48 & 27.41 & 6.11 & 0.00 \\
\hline
\end{tabular}

\subsection{Diagenesis}

The tight sandstone of the coal measures in the study area underwent a complex diagenetic transformation process. The main types of diagenesis include compaction, cementation, dissolution, and recrystallization.

The coal-measure tight sandstone had a relatively fine grain size, high content of plastic cuttings and miscellaneous bases, weaker compaction resistance, and high overall compaction strength. The shallow buried depth of the cored well section and the filling of miscellaneous bases made up the reservoir particles, and the contact relationship was mainly point-line contact. In addition, the flexural deformation of plastic particles, such as mica, and the compaction and crushing of brittle particles, such as feldspar, were common.

The dissolution of tight sandstones in the study area was generally developed, but the intensity was low. Among them, the dissolution of feldspar particles was the most common, and most of the dissolutions were weak, forming intragranular pores of feldspar or rock fragments (Figure $4 \mathrm{c}, \mathrm{e}$ ); the secondary pores ratio was between $0 \%$ and $3 \%$. In some areas, such as Well Ganggu 1-1, the dissolution was strong. Mold holes were common (Figure 5a), and the secondary hole ratio reached $6 \%$. Moreover, a small amount of carbonate cement dissolution could be observed.

There are various types of sandstone cementation in the study area, which are caused by various carbonate cements, including calcite and iron calcite, followed by various clay mineral cements, such as kaolinite, illite, chlorite, authigenic quartz, and quartz. Cement mostly occurred as filling pores, especially carbonate cement filling intergranular pores or feldspar dissolution pores (Table 4). 
Table 4. Relative content of clay minerals in typical wells. / means no data.

\begin{tabular}{|c|c|c|c|c|c|c|c|}
\hline \multirow{2}{*}{ Well } & \multicolumn{6}{|c|}{ Minerals Content (w\%) } & \multirow{2}{*}{$\begin{array}{c}S \% \\
\text { in } I / S\end{array}$} \\
\hline & Illite & Smectite & $\mathrm{I} / \mathrm{S}$ & Kaolinite & Chlorite & $\mathrm{C} / \mathrm{S}$ & \\
\hline \multirow{2}{*}{ Donggu 1} & $21.42-69.89$ & $\underline{0-9.27}$ & $1.68-36.75$ & $\underline{0-42.83}$ & $12.79-24.70$ & $\underline{0-20.47}$ & $\underline{15-65}$ \\
\hline & 42.48 & 1.32 & 15.57 & 18.61 & 19.09 & 2.92 & 25 \\
\hline \multirow{2}{*}{ Nv 51} & $\underline{15.58-33.19}$ & $\underline{0-19.6}$ & $\underline{0-23.87}$ & $\underline{32.36-79.83}$ & $\underline{0-26.07}$ & \multirow{2}{*}{2.02} & $\underline{0-75}$ \\
\hline & 23.04 & 2.5 & 8.27 & 53.35 & 12.84 & & 38 \\
\hline \multirow[b]{2}{*}{ Kou 38-16 } & $\underline{4.19-30.95}$ & & $\underline{1.54-18.7}$ & $\underline{50.35-94.27}$ & $\underline{0-9.61}$ & \multirow[b]{2}{*}{7} & $\underline{10-82}$ \\
\hline & 12.76 & I & 6.56 & 79.81 & 0.87 & & 25 \\
\hline \multirow{2}{*}{ Kou 11} & $\underline{19.01-27.62}$ & & $\underline{58.89-63.8}$ & $\underline{13.5-17.19}$ & $\underline{0-15.67}$ & \multirow[b]{2}{*}{ / } & $\underline{82-85}$ \\
\hline & 23.31 & 1 & 61.34 & 15.34 & 1.52 & & 84 \\
\hline \multirow[b]{2}{*}{ Kou 24} & $\underline{0-24.71}$ & $\underline{0-19.6}$ & $\underline{0-32.27}$ & $\underline{43.02-69.12}$ & $\underline{0-14.27}$ & \multirow[b]{2}{*}{1} & $\underline{10-65}$ \\
\hline & 7.98 & 4.5 & 9.1 & 59.45 & 1.25 & & 25 \\
\hline
\end{tabular}

Note: I/S: Illite-smectite mixed-layer mineral; C/S: Chlorite-smectite mixed layer mineral; $\frac{\text { minimum-maximum }}{\text { averge value }}$.

\section{Discussion}

\subsection{Diagenetic Sequences Affected by Differential Tectonic Evolution}

When the Carboniferous-Permian Taiyuan Formation and Shanxi Formation were deposited, the sedimentary environment of the study area evolved from marine to marineterrestrial transitional facies to continental facies [7]. The dominant sedimentary microfacies types were barrier sand dams in the barrier island environment and delta plain diversion channels. Its lithology was expressed as mudstone and sandstone interbedded with coal, limestone, or sand-mudstone interbedded with coal. Sandstone and argillaceous sediments were frequently interbedded and were close to or adjacent to the source rock. Sandstones were mostly produced in thin layers, and the development of thick sand bodies was limited. This type of formation had a low sand-to-ground ratio and poor connectivity between the sand bodies. The Xiashihezi Formation directly covers the Shanxi Formation and is far from the coal-measure source rocks. The geological history has experienced multiple periods of structural uplift and subsidence (Figure 6). The northern part of the study area was steadily deposited in the Early-Middle Triassic of the Mesozoic period and was compressed and uplifted in the Indosinian of the Late Triassic period. The strata suffered from denudation. NWW-trending folds developed in the east, and the denudation was stronger than that in the west. Inheriting the Indosinian tectonic framework, NE-trending folds developed in the west from the early Middle Jurassic. At this time, the tectonic framework was "high in the west and low in the east." In the late Jurassic to the middle of the Early Cretaceous period, NNE (NE) trending basin-controlling faults formed and controlled deposition. In the late Yanshanian period of the Late Cretaceous period, the early normal faults reversed to thrust, and the stratum was denuded. In the Paleogene, the basin entered the rifting period, the early active faults were mainly tensile, and secondary faults developed [21]. From the Neogene to the Quaternary period, the basin as a whole was in the depression stage, with developed secondary faults and stable lateral deposits (Figure 6). Tectonic evolution corresponds to the differences in the evolutionary process of the Upper Paleozoic period in different regions. Tectonic evolution affects diagenesis by affecting the burial depth of the reservoir and the communication between the fractures and the surface, which in turn influences the effect of reservoir reformation. 


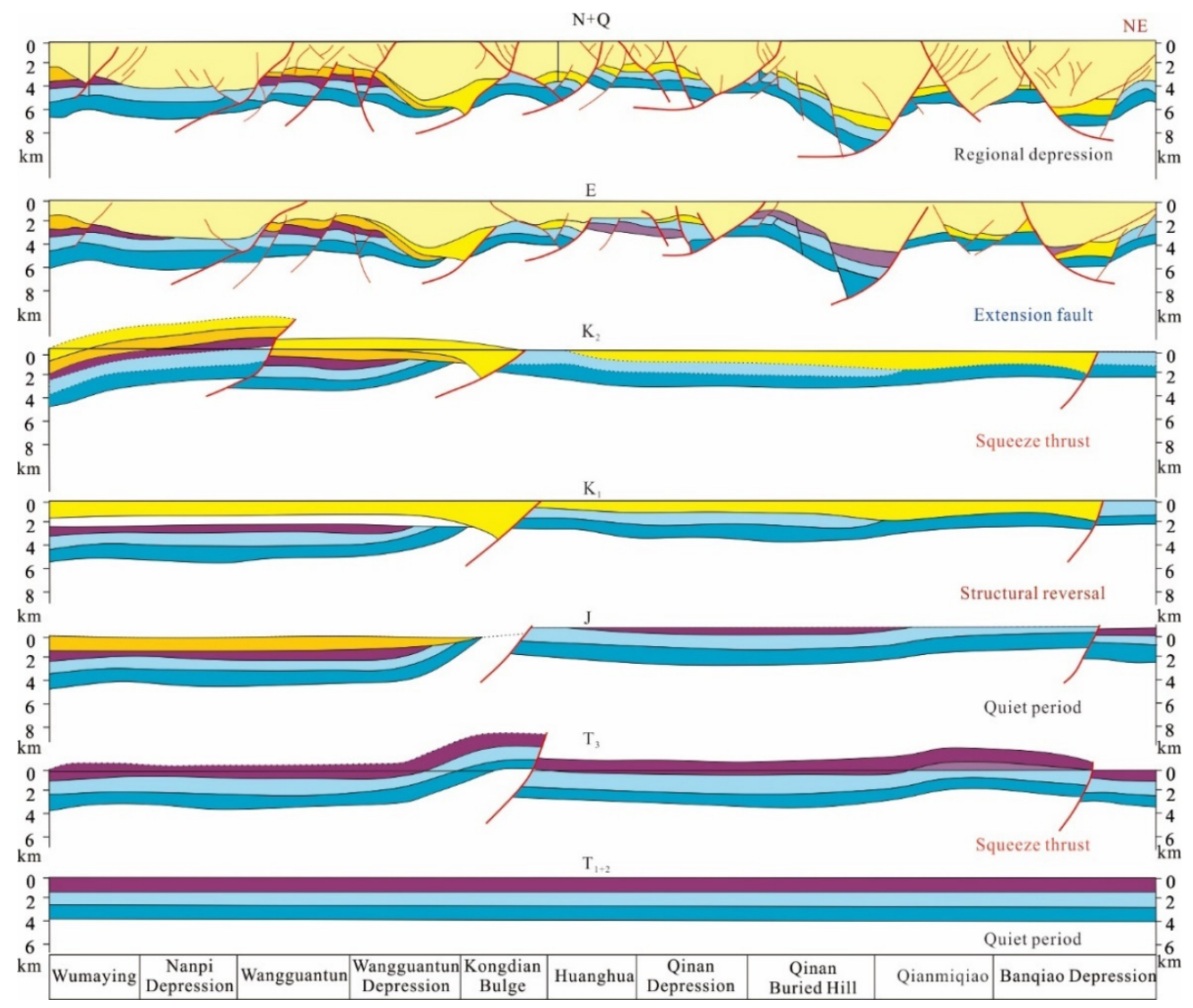

Figure 6. Sections of regional structural evolution of Wumaying-Wangguantun-Kongdian-HuanghuaQikou Beidagang-Banqiao in different periods.

The meandering point sand bar in the study area had good original properties, a thick single sand body, and effective sand body connectivity, which provide powerful conditions for the migration of formation fluids along the bed. The local area of uplift and denudation suffered from wind leaching, and the generation of acid from organic matter in coal measures in the later stage, the combined action of atmospheric leaching under the uplifting open system, and the generation of acid from coal source rocks at the burial stage improved the physical properties of sandstone reservoirs in the study area, with higher rigid particle content and early oil and gas charging preserved sandstone pores.

\subsection{Physical Property Variations Affected by Different Diagenesis}

The thin sand bodies and thick sand bodies in the study area were close to the sand-mud interface, and carbonate cements were generally well developed. There were relatively few carbonate cements in thick sand bodies far away from the sand-mud interface. The relationship between the physical properties of the sandstone and the sand body thickness/sand-mud interface distance in the statistical study area (Figure 7a,b) showed that there is a positive correlation between the physical properties and the sand body thickness and the sand-mud interface distance. The physical properties of thick sandstone reservoirs were relatively high, and when the distance between the sample and the sandmud interface was less than $1 \mathrm{~m}$, the reservoir porosity was less than $5 \%$. The reason for this phenomenon is that in an alkaline environment, the montmorillonite in the mudstone transforms into the Iraqi/smectite layer and dehydrates the gypsum to release a large amount of $\mathrm{Ca}^{2+}$, and metal ions, such as $\mathrm{Mg}^{2+}$ and $\mathrm{Fe}^{2+}$ enter the sand body to form carbonate cement fillings in pores. The concentration of metal ions was the largest at the contact between sand and mud and gradually decreased toward the interior of the sand body, resulting in tight cementation at the edge of the sand body and severe damage to the pores of the reservoir. Under such conditions, it is difficult for oil and gas to enter, 
and the effect of acidic fluid on its transformation in the later stage is also inhibited. Limited by the migration distance of the original material of the cement, the degree of carbonate cementation in the sand body was low; thus, a large number of pores could be preserved. Therefore, the sandstone in the study area exhibits a strong cementation at the sand-mudstone interface and gradually weakens the cementation degree inside the sand body.
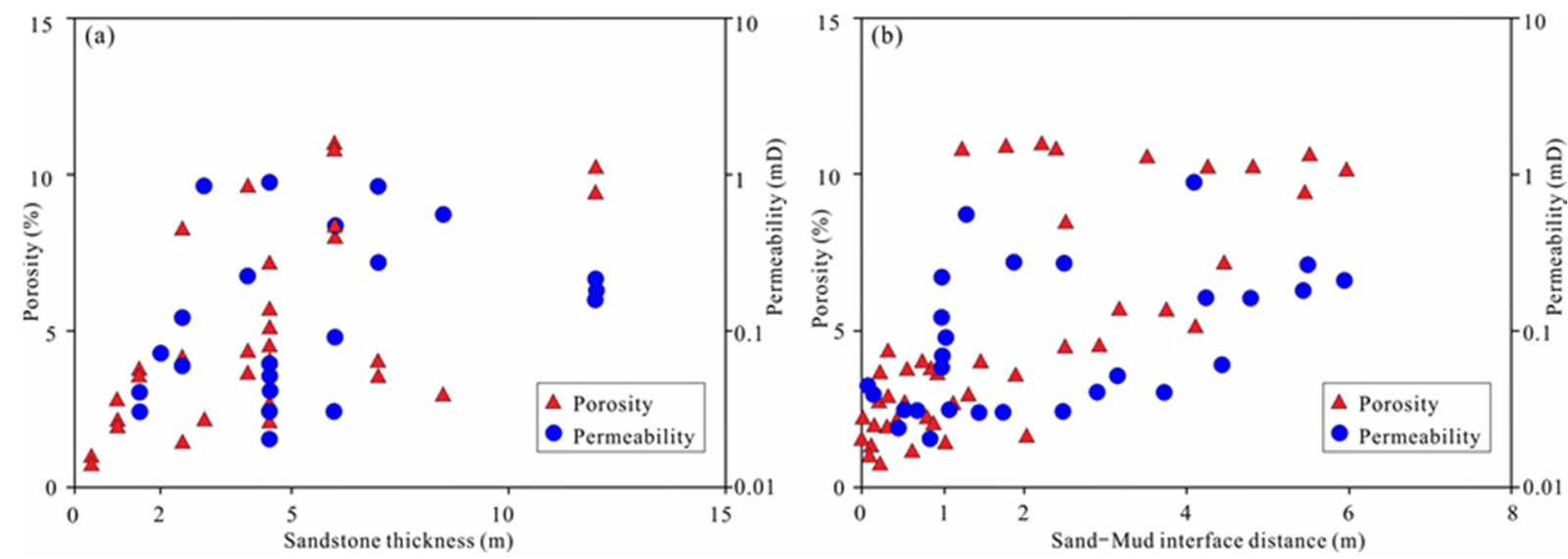

Figure 7. The porosity of sandstones. (a), Sandstone thickness relationship with porosity; (b), sandstones-mudstones interface distances relationship with porosity.

The dissolution of feldspar in sandstone reservoirs can form secondary pores, accompanied by by-products, such as kaolinite and quartz cement [29-31]. According to the statistics of its content using casting thin slices, the average content of feldspar dissolved pores in the Permian reservoirs in the study area can reach $4.38 \%$, whereas the content of authigenic kaolinite was $1.1 \%$, the content of siliceous cement was $3.4 \%$, and the content of feldspar corrosion was significantly larger than that of authigenic minerals (Figure 8a-c), indicating that most of the feldspar dissolution products were transported out of the leaching dissolution zone at the top of the buried hill.
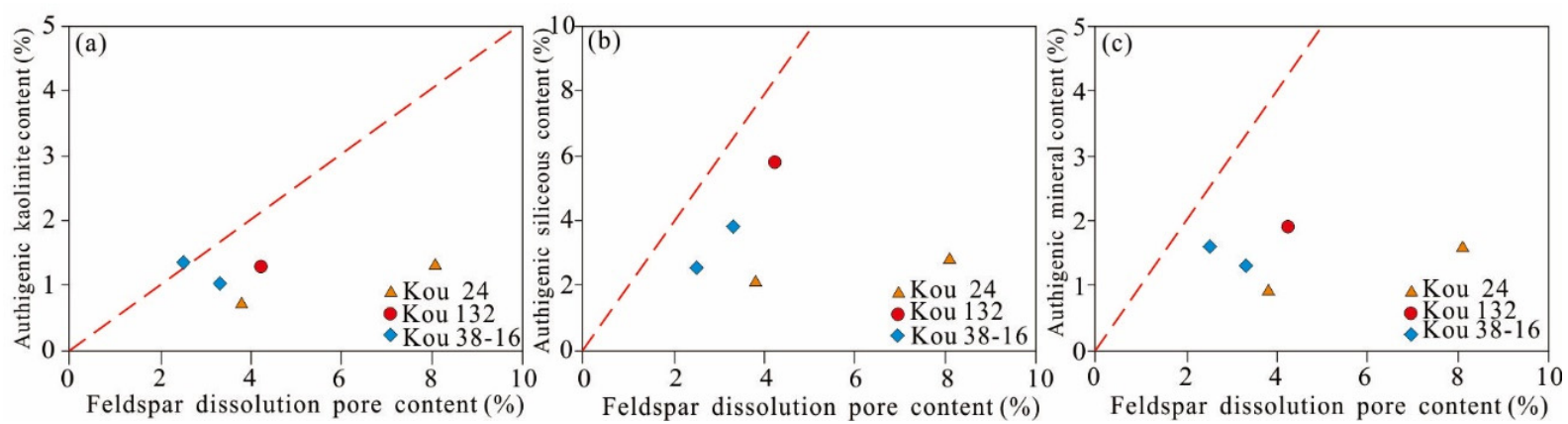

Figure 8. Quantitative relationship between feldspar dissolution pores content and authigenic minerals. (a), Relationship with authigenic kaolinite; (b), relationship with authigenic silicate; (c), relationship with authigenic clay minerals.

\subsection{Formation Models of the Tight Sandstone Reservoirs}

During the formation of the buried hill, the sand bodies were in different structural positions during different periods. For example, the wells 38-16 at the top of the buried hill in Kecun today, during the two stratigraphic uplifting processes of the Late Triassic and the Early Paleogene periods (Figure 9). At the top of the mountain, the Guangu 1601 well at the top of the Wangguantun buried hill was in the buried hill slope area during the Late Triassic period, and the stratum inverted during the later burial process [32,33]. The top of the early buried hill is now in a buried hill slope area. Results of the analysis of the structural evolution process of the main buried hills in the study area, summary of the 
following structural superimposition-acid source relay evolution model, and results of the analysis of the diagenetic evolution process of different types of buried hill reservoirs are provided in Figure 9.

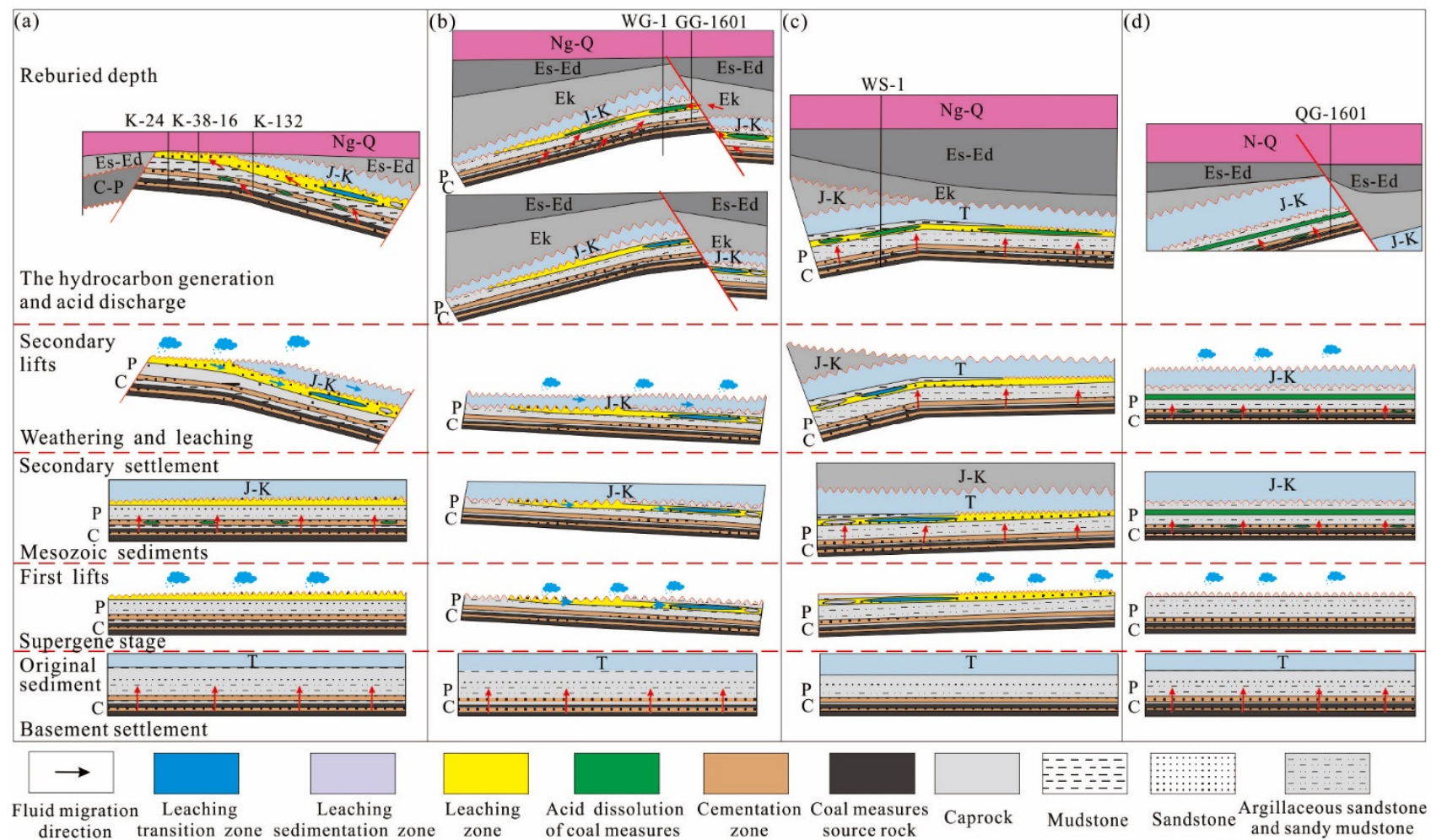

Figure 9. Tight sandstone formation mechanism of the study area. (a), Atmospheric leaching type in Koucun area; (b), combined control type of atmospheric water and organic acid in Wangguantun; (c), combined control type of atmospheric water and organic acid in Wumaying; (d), organic acid dominant types in Nandagang. Ng-Q: Neogene to Quaternary, P: Permian, C: Carbonaceous; J-K: Jurassic to Cretaceous, T: Triassic, Es: Eocene Shahejie Formation, Ed: Eocene Dongying Formation; Ek: Eocene Kongdian Formation.

According to the different burial processes, the burial history can be divided into three types. The first is represented by the Koucun buried hill. The Upper Paleozoic Shiqianfeng Formation is completely denuded, and the Upper Shihezi Formation is directly connected to the overlying Paleogene. The second type is represented by the buried hills of Wangguantun and Wumaying. The Shiqianfeng Formation in the Wangguantun area is severely denuded and partially remains. The upper Shihezi Formation strata and the overlying thin Shiqianfeng Formation or Jurassic strata direct contact and regional unconformity develop. The third type is represented by the Nandagang area, where the upper Shihezi Formation sand body in the Nandagang area is covered with thick Shiqianfeng Formation, and there is no obvious regional angular unconformity.

\section{Conclusions}

Combining thin section, porosity, mercury injection, hydrochemistry, and basin simulation results, the petrology and physical property of tight sandstone in the Upper Paleozoic, Bohai Bay Basin, eastern China was investigated, and the following conclusion was reached:

The sandstones are mainly of feldspar, lithic feldspar, feldspar lithic, and feldspar lithic quartz sandstones. The quartz content varies between $25 \%$ and $70 \%$, averaging $41 \%$. Feldspar and debris content are generally high, averaging $31 \%$ and $28 \%$, respectively. The sandstones are generally of poor physical property, with $45 \%$ of samples having porosity of $5 \% \sim 10 \%$ and $15 \%$ samples lower than $5 \%$. 
The sandstone mainly contains intergranular dissolution and intragranular dissolution pores, with a few microfractures. The pore radium is generally lower than $100 \mathrm{~nm}$, showing small to medium pores with fine to medium throats.

Tectonic evolution and its related diagenetic sequences control sandstone physical property variation. And the key reasons dominating high-porosity sandstone formation can be recognized, which are atmospheric leaching dominant (Koucun buried hill), atmospheric water and organic acid co-controlled (Wangguantun and Wumaying buried hills), and organic acid dominant (Nandagang buried hill) influences.

Author Contributions: Conceptualization, L.Z., F.J. and Y.L.; methodology, W.X.; validation, L.D. and L.F.; formal analysis, W.X.; investigation, Y.L.; resources, L.Z. and F.J.; data curation, H.L. (Hongjun Li) and H.L. (Haitao Liu); writing-original draft preparation, Y.L. and W.X.; writingreview and editing, L.Z.; visualization, X.P.; supervision, F.J.; project administration, L.Z.; funding acquisition, L.Z. and F.J. All authors have read and agreed to the published version of the manuscript.

Funding: This study was founded by the National Science Foundation of China (Grant No. 42072194), the Major National Science and Technology Project of China (No. 2016ZX05066001-002).

Acknowledgments: The authors thank Dagang Oil Co. of CNPC and Research Institute of Petroleum Exploration and Development for providing testing samples and our colleagues for the beneficial suggestion.

Conflicts of Interest: We declare that we have no financial and personal relationships with other people or organizations that can inappropriately influence our work, there is no professional or other personal interest of any nature or kind in any product, service and/or company that could be construed as influencing the position presented in, or the review of, the manuscript entitled.

\section{References}

1. Dai, J.X.; Wu, W.; Fang, C.C.; Liu, D. Exploration and development of large gas fields in China since 2000. Nat. Gas Ind. B 2015, 2, 1-8. [CrossRef]

2. Zou, C.N.; Yang, Z.; Huang, S.P.; Ma, F.; Sun, Q.P.; Li, F.H.; Pan, S.Q.; Tian, W.G. Resource types, formation, distribution and prospects of coal-measure gas. Pet. Explor. Dev. 2019, 46, 451-462. [CrossRef]

3. Li, Y.; Yang, J.H.; Pan, Z.J.; Meng, S.Z.; Wang, K.; Niu, X.L. Unconventional natural gas accumulations in stacked deposits: A discussion of Upper Paleozoic coal-bearing strata in the east margin of the Ordos Basin, China. Acta Geol. Sin. 2019, 93, 111-129. [CrossRef]

4. Dai, J.X.; Ni, Y.Y.; Dong, D.Z.; Qin, S.F.; Zhu, G.Y.; Huang, S.P.; Yu, C.; Gong, D.Y.; Hong, F.; Zhang, Y.L.; et al. $2021-2025$ is a period of great development of China's natural gas industry: Suggestions on the exploration and development of natural gas during the 14th Five-Year Plan in China. Nat. Gas Geosci. 2021, 6, 183-197. [CrossRef]

5. Sternbach, C.A. AAPG Super Basin Initiative. AAPG Bull. 2018, 102, 7-8. [CrossRef]

6. Roller, E.; Pepper, A. Estimating the ultimate expellable potential of source rocks: Defining "world class" for aquatic organofacies with examples from the Arabian, West Siberian, Bohai, and Williston Basins. In Proceedings of the AAPG Annual Convention and Exhibition 2017, Houston, TX, USA, 2-5 April 2017; p. 11055.

7. Yang, R.Z.; Zhao, X.Z.; Liu, H.T.; Zhao, C.Y.; Li, H.J.; Pu, X.G.; Fu, L.X.; Li, C.M. Hydrocarbon charging and accumulation in the Permian reservoir of Wangguantun Buried Hill in Huanghua Depression, Bohai Bay Basin, China. J. Pet. Sci. Eng. 2021, 199, 108297. [CrossRef]

8. Yuan, G.H.; Cao, Y.C.; Sun, P.P.; Zhou, L.H.; Li, W.; Fu, L.X.; Li, H.J.; Lou, D.; Zhang, F.P. Genetic mechanisms of Permian Upper Shihezi sandstone reservoirs with multi-stage subsidence and uplift in the Huanghua Depression, Bohai Bay Basin, East China. Mar. Pet. Geol. 2021, 124, 104784. [CrossRef]

9. Chang, J.; Qiu, N.S.; Zhao, X.Z.; Shen, F.Y.; Liu, N.; Xu, W. Mesozoic and Cenozoic tectono-thermal reconstruction of the western Bohai Bay Basin (East China) with implications for hydrocarbon generation and migration. J. Asian Earth Sci. 2018, 160, 380-395. [CrossRef]

10. Teng, C.Y.; Zou, H.Y.; Hao, F. Control of differential tectonic evolution on petroleum occurrence in Bohai Bay Basin. Sci. China Earth Sci. 2014, 57, 1117-1128.

11. Liu, Y.F.; Hu, W.X.; Cao, J.; Wang, X.L.; Tang, Q.S.; Wu, H.G.; Kang, X. Diagenetic constraints on the heterogeneity of tight sandstone reservoirs: A case study on the Upper Triassic Xujiahe Formation in the Sichuan Basin, southwest China. Mar. Pet. Geol. 2018, 92, 650-669. [CrossRef]

12. Li, Y.; Gao, X.D.; Meng, S.Z.; Wu, P.; Niu, X.L.; Qiao, P.; Elsworth, D. Diagenetic sequences of continuously deposited tight sandstones in various environments: A case study from upper Paleozoic sandstones in the Linxing area, eastern Ordos basin, China. AAPG Bull. 2019, 103, 2757-2783. [CrossRef]

13. Yilmaz, M.; Tuğrul, A. The effects of different sandstone aggregates on concrete strength. Constr. Build. Mater. 2012, 35, $294-303$. [CrossRef] 
14. Petrounias, P.; Giannakopoulou, P.P.; Rogkala, A.; Kalpogiannaki, M.; Koutsovitis, P.; Damoulianou, M.; Koukouzas, N. Petrographic Characteristics of Sandstones as a Basis to Evaluate Their Suitability in Construction and Energy Storage Applications. A Case Study from Klepa Nafpaktias (Central Western Greece). Energies 2020, 13, 1119. [CrossRef]

15. Qi, J.F.; Yang, Q. Cenozoic structural deformation and dynamic processes of the Bohai Bay basin province, China. Mar. Pet. Geol. 2010, 27, 757-771. [CrossRef]

16. Mohammed, R.A.; Zhu, X.M. Deformational Mechanism and Tectonic Evolution of Mesozoic-Cenozoic Nonmarine Basins from Bohai Bay Basin-China. J. Eng. Comput. Sci. 2019, 15, 8-25.

17. Zhou, L.H.; Fu, L.X.; Lou, D.; Lu, Y.; Feng, J.Y.; Zhou, S.H.; Santosh, M.; Li, S.Z. Structural anatomy and dynamics of evolution of the Qikou Sag, Bohai Bay Basin: Implications for the destruction of North China Craton. J. Asian Earth Sci. 2012, 47, 94-106. [CrossRef]

18. Li, M.W.; Chen, Z.H.; Ma, X.X.; Cao, T.T.; Qian, M.H.; Jiang, Q.G.; Tao, G.L.; Li, Z.M.; Song, G.Q. Shale oil resource potential and oil mobility characteristics of the eocene-oligocene Shahejie Formation, Jiyang super-depression, Bohai Bay Basin of China. Int. J. Coal Geol. 2019, 204, 130-143. [CrossRef]

19. Yan, J.P.; Fan, J.; Wang, M.; Li, Z.Z.; Hu, Q.H.; Chao, J. Rock fabric and pore structure of the Shahejie sandy conglomerates from the Dongying depression in the Bohai Bay Basin, East China. Mar. Pet. Geol. 2018, 97, 624-638. [CrossRef]

20. Yin, X.D.; Jiang, S.; Chen, S.J.; Wu, P.; Gao, W.; Gao, J.X.; Shi, X. Impact of rock type on the pore structures and physical properties within a tight sandstone reservoir in the Ordos Basin, NW China. Pet. Sci. 2020, 17, 896-911. [CrossRef]

21. Xi, K.L.; Cao, Y.C.; Liu, K.Y.; Wu, S.T.; Yuan, G.H.; Zhu, R.K.; Kashif, M.; Zhao, Y.W. Diagenesis of tight sandstone reservoirs in the Upper Triassic Yanchang formation, southwestern Ordos Basin, China. Mar. Pet. Geol. 2019, 99, 548-562. [CrossRef]

22. Li, Y.; Tang, D.Z.; Wu, P.; Niu, X.L.; Wang, K.; Qiao, P.; Wang, Z.S. Continuous unconventional natural gas accumulations of Carboniferous-Permian coal-bearing strata in the Linxing area, northeastern Ordos basin, China. J. Nat. Gas Sci. Eng. 2016, 36, 314-327. [CrossRef]

23. Yuan, G.H.; Cao, Y.C.; Gluyas, J.; Li, X.Y.; Xi, K.L.; Wang, Y.Z.; Jia, Z.Z.; Sun, P.P.; Oxtoby, N.H. Feldspar dissolution, authigenic clays, and quartz cements in open and closed sandstone geochemical systems during diagenesis: Typical examples from two sags in Bohai Bay Basin, East China. AAPG Bull. 2015, 99, 2121-2154. [CrossRef]

24. Gonfiantini, R. Standards for stable isotope measurements in natural compounds. Nature 1978, 271, 534-536. [CrossRef]

25. Lai, J.; Wang, G.W.; Ran, Y.; Zhou, Z.L. Predictive distribution of high-quality reservoirs of tight gas sandstones by linking diagenesis to depositional facies: Evidence from Xu-2 sandstones in the Penglai area of the central Sichuan basin, China. J. Nat. Gas Sci. Eng. 2015, 23, 97-111. [CrossRef]

26. Li, Y.; Wang, Z.S.; Pan, Z.J.; Niu, X.L.; Yu, Y.; Meng, S.Z. Pore structure and its fractal dimensions of transitional shale: A cross-section from east margin of the Ordos Basin, China. Fuel 2019, 241, 417-431. [CrossRef]

27. Chen, L.; Jiang, Z.X.; Liu, K.Y.; Tan, J.Q.; Gao, F.L.; Wang, P.F. Pore structure characterization for organic-rich Lower Silurian shale in the Upper Yangtze Platform, South China: A possible mechanism for pore development. J. Nat. Gas Sci. Eng. 2017, 46, 1-15. [CrossRef]

28. Zou, C.N.; Zhu, R.K.; Liu, K.Y.; Su, L.; Bai, B.; Zhang, X.X.; Yuan, X.J.; Wang, J.H. Tight gas sandstone reservoirs in China: Characteristics and recognition criteria. J. Pet. Sci. Eng. 2012, 88, 82-91. [CrossRef]

29. Baiyegunhi, C.; Liu, K.W.; Gwavava, O. Diagenesis and reservoir properties of the Permian Ecca Group sandstones and mudrocks in the Eastern Cape Province, South Africa. Minerals 2017, 7, 88. [CrossRef]

30. Chima, P.; Baiyegunhi, C.; Liu, K.W.; Gwavava, O. Diagenesis and rock properties of sandstones from the Stormberg Group, Karoo Supergroup in the Eastern Cape Province of South Africa. Open Geosci. 2018, 10, 740-771. [CrossRef]

31. Folk, R.L. Petrology of Sedimentary Rock, 2nd ed.; Hemphill Press: Austin, TX, USA, 1974; 182p.

32. Huang, L.; Liu, C.Y.; Wang, Y.B.; Zhao, J.F.; Mountney, N.P. Neogene-Quaternary postrift tectonic reactivation of the Bohai Bay Basin, eastern ChinaPostrift Tectonic Reactivation of the Bohai Bay Basin. AAPG Bull. 2014, 98, 1377-1400. [CrossRef]

33. Yu, F.S.; Koyi, H. Cenozoic tectonic model of the Bohai Bay Basin in China. Geol. Mag. 2016, 153, 866-886. [CrossRef] 